\title{
ELEMENTS OF ENGINEERING GEOLOGY AND GEOTECHNICAL ENGINEERING IN THE HOMERIC POEMS
}

\author{
Dimitrios Zekkos, PhD, GeoSyntec Consultants \\ George Athanasopoulos, Professor, Department of Civil Engineering, University of \\ Patras \\ Adda Athanasopoulos, MSc, Doctoral Student, Department of Civil and \\ Environmental Engineering, University of California at Berkeley, \\ John Manousakis, MSc, Dromos Consulting
}

\section{ABSTRACT}

The Homeric epic poems are among the oldest texts in European history. This paper examines the information provided by Homer related to the fields of engineering geology and geotechnical engineering. The information is subsequently compared against archaeological findings. The Homeric descriptions of battle scenes, of ancient cities and the geologic environment suggest that an understanding of some of the geologic processes already existed at the time of Homer, probably as a result of observations of the environment. A study of the geologic descriptors reveals that Homer was particularly careful in the selection of the words he used in his descriptions. The poems also provide some insight into issues related to geotechnical engineering. Homer describes a deep excavation, which was constructed by the ancient Greeks for defensive purposes and failed during the Trojan war. Based on the Homeric characterizations, the defensive excavation appears to have been an interesting and impressive technical project. In addition, a variety of engineering projects are mentioned, such as roads, embankments, and harbors. Of particular interest are also Homer's comments on the causes of various failures. The information provided on topics related to the field of engineering geology and geotechnical engineering is remarkable given the scope of the poems.

\section{INTRODUCTION}

The Homeric poems have been a source of inspiration since the ancient years: Virgil was inspired by Homer to write the Aeneid; Alexander the Great used to sleep with a copy of the Iliad next to him; and the historian Diodoros of Sicily refers with great respect to Homer and considers him the oldest and most celebrated poet. Diodoros also considered Homer and Isiod the most distinguished of all men. Themes from Homer's poems have inspired numerous works of art from the ancient years until present. In addition to their literary value, the Homeric poems are also important because they refer to a period of time for which very limited written information is preserved, the Mycenaean Civilization. The Homeric poems are probably the most important source of information regarding the values, traditions and habits of the Mycenaeans. However, it is estimated that the Trojan war took place sometime early in the $12^{\text {th }}$ Century BC while Homer lived about 400 years later $\left(8^{\text {th }}\right.$ Century BC), so a recurrent problem when collecting information from these poems is whether Homer refers to facts of the Mycenaean Civilization or is influenced by his own time. However, in general, much of the information provided by Homer on the Mycenaean civilization has been consistent with archaeological evidence. Schliemann used Homer's poems to identify the location of the city of Troy and unearth his findings in Mycenae and Tiryns [1, 2]. Of particular interest is the information provided by 
Homer on topics related to science and technology, such as physics, hydraulics, psychology, naval engineering, astronomy, civil engineering, and military science. These have been the topic of study by many researchers. In particular, this paper examines information provided by Homer in the fields of engineering geology and geotechnical engineering.

\section{GEOLOGIC DESCRIPTIONS}

When Homer refers to various cities or regions, he commonly uses geologic descriptors. For example, in the Iliad, the poet refers to sandy Pylos (I, 153), the

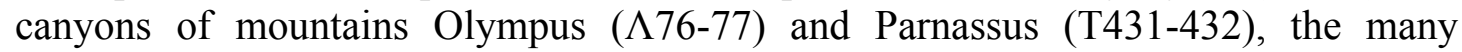
springs of Ida (Y218), and the wide and deep river Axios (Ф141-142). Similarly in Odyssey, the poet refers to sandy Sparta and Pylos (A93), to the many canyons of

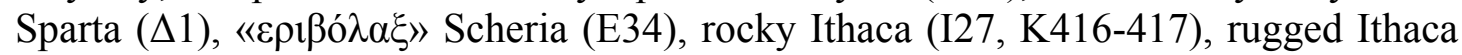

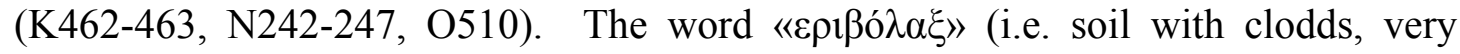
fertile) is repeatedly used to characterize rich, flourishing cities or places. It is used for Askania (Iliad N793), Lycia (Iliad P172), Scheria (Odyssey E34), Tarni (Iliad E44), twice for Paionia (Iliad Ф154, P350), twice for Thrace (Iliad 1222 , Y485), twice for the city of Larisa (Ilias B841, P301) three times for the city of Achilles, Phthia (Iliad A155, I362, I478) and seven times for the city of Troy (Iliad Г74, Г257, Z314, I329, П460, $\Sigma 67, \Omega 86$ ).

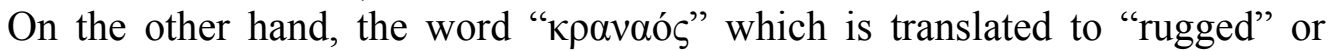
"rocky" $[3,4,5]$ is used a total of 5 times in the Iliad (Г201) and Odyssey (A247, O510, П124, Ф346). In all occurrences, it is used to describe Ithaca. It is not used to describe any other city or place. This epithet is also one of the common descriptors used for Ithaca. The word « $\pi \alpha \imath \pi \alpha \lambda$ ó $1 \zeta »$ (i.e. craggy, rugged) is used also for Ithaca (Odyssey $\Lambda 480$ ) but also for the islands of Sami (Odyssey, O29, $\Delta 670, \Delta 845$ ), Chios (Odyssey $\Gamma 170$ ), for a mountain in Samothrace (Iliad N17), Imvros (Iliad N33, $\Xi 280$, $\Omega 78$ ). In fact, the island of Imvros is only mentioned four times in the two poems, of which only two times a descriptor is used and in both cases the same epithet is used. From the above observations, it becomes apparent that Homer is consistent in his geologic descriptions in both poems and is also very careful in the selection of the attributed epithets, which are also accurate descriptions of the geologic environments of the places mentioned.

\section{GEOLOGIC PROCESSES}

The Homeric descriptions also suggest the existence of the first elements of knowledge of various geologic processes by Homer's time. This knowledge was likely the result of observations of the geologic environment. For pre-industrial societies, observing the environment was an integral part of the survival and continued growth of the society as ancient economies depended primarily on agriculture and sea commerce. Some of the geologic information provided by Homer is reviewed in the following sections.

\subsection{Riverine environment and deposits}

Homer's texts refer on several occasions to the riverine geologic environment. Simple observations such as that rivers form in the mountains and empty in the seas were certainly made early on in the history of mankind and are mentioned in the Iliad. 
Of particular interest is the description in the Iliad where Skamander river becomes "infuriated" by the number of dead bodies that Achilles throws in the river's waters during the battle. The river threatens the hero that if he continues his actions, he will be covered first with a layer of sand, then with a layer of gravel and finally with a layer of mud. The poet refers to three different soil layers, all of which are typical riverine deposits.

In another example (Iliad, M10-33) the poet refers to the destruction of the defensive wall of the Achaeans after the end of the war by the combined forces of Poseidon, Apollo and Zeus. Homer describes in great detail that the courses of eight rivers were changed so that their combined flows could destroy the walls, while at the same time Zeus arranged for rain to support the effort. Homer describes that after the flood and the destruction of the walls, the entire area was leveled and covered with sand (H459-463). River flooding and intense rainfall were already two correlated events at Homer's time. In another instance (Iliad, $1492-495)$ Homer mentions that rainfall results in flooding of the rivers which transfer wood, soil and bushes up to the coast, while in Iliad T205-207 Homer describes that as the snow melts, the rivers swell.

Again, it is not surprising for agriculture-dependent societies that these observations were already made. In fact, flooding protection, river course modification, and drainage of lakes to create more land for irrigation were among the first civil engineering infrastructure built. There is ample Mycenaean archaeological evidence of large-scale hydraulic systems that consisted of embankments, tunnels and excavations that allowed the drainage of lakes and the creation of land for agriculture $[6,7,8]$.

\subsection{Soil types}

In the numerous occasions that the poet refers to earth materials there is a clear discrimination between sand, soil, gravel and rock. Sand is mentioned repeatedly to describe the coastlines near Troy, as well as the coasts of other areas. The poet refers to the anchoring of the ships on the sand beaches at the shallow waters (Odyssey, $\Delta 426$, I546-547) and differentiates between the sandy coasts (Iliad, I182, Odyssey, $\Gamma 39, \Delta 432$, I74, I552) and the coasts with gravel or pebbles (Odyssey, Z94-95). In the Iliad, the poet describes the fall of Mydon's coachman from the chariot. The warrior falls head first and the poet describes that he was stuck there with his head in the sand for some time because the sand was deep. Sands are also mentioned as part of the riverine deposits, as discussed previously. In a distinctly different type of soil refers

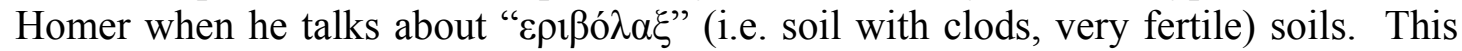
epithet is used to describe the wealth of a city as discussed earlier. Achilles' shield also illustrates a freshly cultivated, thick, wide field (Iliad, 5541-543), while in the Odyssey (I134-135) the productivity of the soils is attributed to their thickness.

\subsection{Landslides and erosion}

The characteristic steep rock coastlines of many of the Ionian and Aegean islands are used by the poet to characterize strength and endurance against the eroding force of waves (Iliad, O619-621, П34-35, Odyssey, Г293) (Figure 1). In the Odyssey, the poet describes the death of the hero Aiantas. The steep rock where the hero was standing was broken by Poseidon, ruler of the sea, and the hero was killed (Odyssey, $\Delta 501$ 510). The Phaeacians are also afraid of Poseidon, because according to an old 
prophecy their city would be destroyed by being buried by the large mountain rising near the city.

Of great interest is another description in the Iliad (N137-143). The attack of Hector is compared to a rounded rock that detaches from the end of a precipice where it was standing and rolls downhill. The poet explains that the rock detaches due to the intense rainfall and because "the soil that holds the rock breaks due to the plentiful water". The epithet "rounded" is accurately used to describe a rock eroded by water. More importantly, the explanation of the mechanism of the rockfall is provided. The cause of a natural phenomenon is identified, without being attributed to a Godly power, as would be expected 300 years before natural philosophers first tried to explain the causes of the various natural phenomena in the history of mankind.

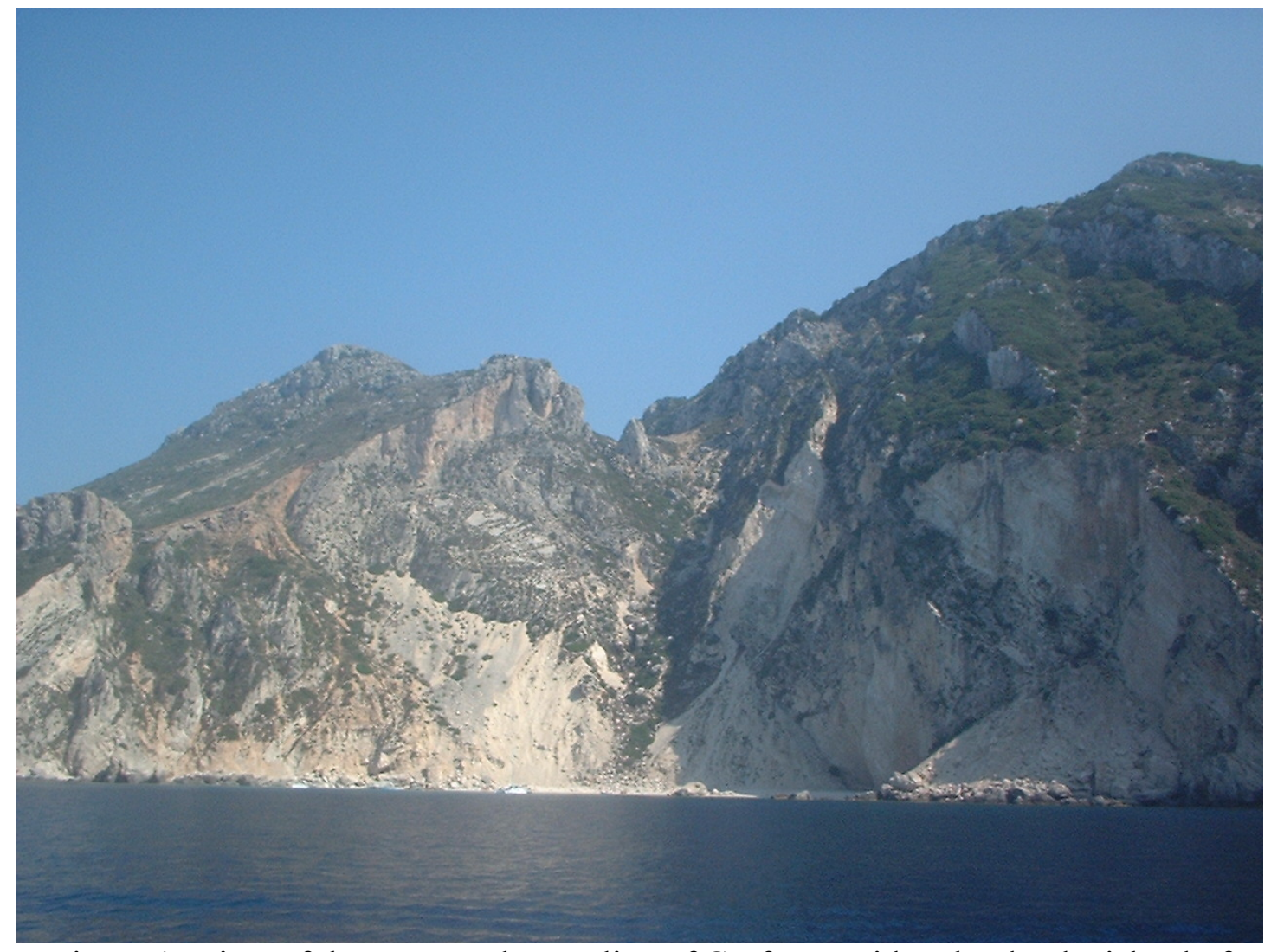

Figure 1: View of the steep rock coastline of Corfu, considered to be the island of Phaeacians.

\subsection{Earthquakes}

Greece has the highest seismic risk in Europe. Earthquakes have shaped human societies in Greece even from the beginning. Over the centuries, Greeks have experienced many earthquakes, some of which resulted in the destruction of civilizations, cities, and the initiation, or interruption of wars [8]. In the Iliad (O177183) Poseidon mentions that in the early times the sky was awarded to Zeus, the Kingdom of the Dead to Hades and the sea to Poseidon. It was decided that the three God-brothers would share the earth. However, Homer refers to Poseidon as the earth's master (Iliad, O174, O222, Odyssey, @350). The most common characterization of Poseidon is "world shaker" (Iliad, N10, Odyssey, E340, Z326, H34-36, I518). This characterization is also found in Isiod [9] and Greek Mythology mentions that Poseidon caused earthquakes. During one of the battles in Troy (Iliad 
Y57-67) Poseidon causes an earthquake. The shaking is so intense that, according to Homer, Hades became worried that the earth would split in two and the Kingdom of the Dead (also known as the Under World) would be revealed to the mortals. To the authors' knowledge this is the first time in literature that there is a direct relation of cause and effect between earthquakes and faults. However, it appears that the relation is reversed, with the cause of the earthquake being Poseidon and the fault being the effect of intense shaking not its cause. It is possible that in a highly seismic region such as Greece, the relation between earth ruptures and earthquakes was established already by Homer's time based on post-earthquake observations. Greece's surface is scarred with numerous faults at short distances from habitated areas. Of interest also is the fact that the poet, in an effort to provide a sense of the magnitude of the event, mentions that the shaking was strongly felt even to the high mountains of Ida, which are located about $60 \mathrm{~km}$ from Troy. Thus, as early as the $9^{\text {th }}$ Century BC, distance was used as a means of indicating the magnitude of an earthquake.

\section{GEOTECHNICAL ENGINEERING}

Information on issues related to the field of geotechnical engineering is also provided in the Homeric poems. While the amount of information is not large, it is still significant, considering the epic scope of the poems.

\subsection{The trench of the Achaeans}

The Achaeans, in an effort to reinforce their defense and protect their ships that were stationed along the coast, constructed a defensive fortification wall and a trench. Achilles, who did not participate in the project because of a disagreement with King Agamemnon, refers specifically to this trench with bitterness, because the Greeks managed to build "a wide and great trench" (Iliad, I348) without his support. Homer describes the trench as deep, wide and large while he also informs us that the Greeks drove into the sides of the trench large wooden piles (Iliad, H435-441).

During the battle, the horses of the Trojans not only could not jump over the trench, but also could not even cross it because the trench sides were vertical. This information is of particular interest because we know that vertical deep trenches in sandy soils, such as the soils that would be expected near the coast, would normally not stand without the necessary support, while vertical trenches of limited depth in more clayey soils would probably stand for only a limited period of time. The poet explains that the Achaeans had placed very large pointed piles, one next to the other in a dense configuration. An interpretation of the Achaean trench based on Homer's description is shown in Figure 1. The trench configuration was such that, as the poet explains, not only the cavalry but also the infantry was wondering how they were going to overcome this obstacle (Iliad, M50-59). The piles were certainly a second line of defense, but it is also likely that they intended to support the deep trench and its vertical sides. If the piles were to serve only for defense then there would be no need to place piles on both sides of the trench as Homer suggests they did. During the battle, the trench failed, allowing the Trojans to attack. Homer provides also details of the failure reporting that Apollo kicked the sides of the trench, which fell into its bottom and created a bridge for the enemy to cross. Homer reports that the length of the failed trench was greater than the distance a human can throw the spear. Thus, the failure is not an isolated local failure, but a global failure of significant size. Is the intervention of a God a way for Homer to explain an apparently inexplicable failure of 
a project that has been constructed before or was it the first time that a trench of that scale was constructed? We do not know. The second explanation is however, supported by the epithets attributed to the trench and the expressions of admiration not only of the enemy, but also of Achilles.

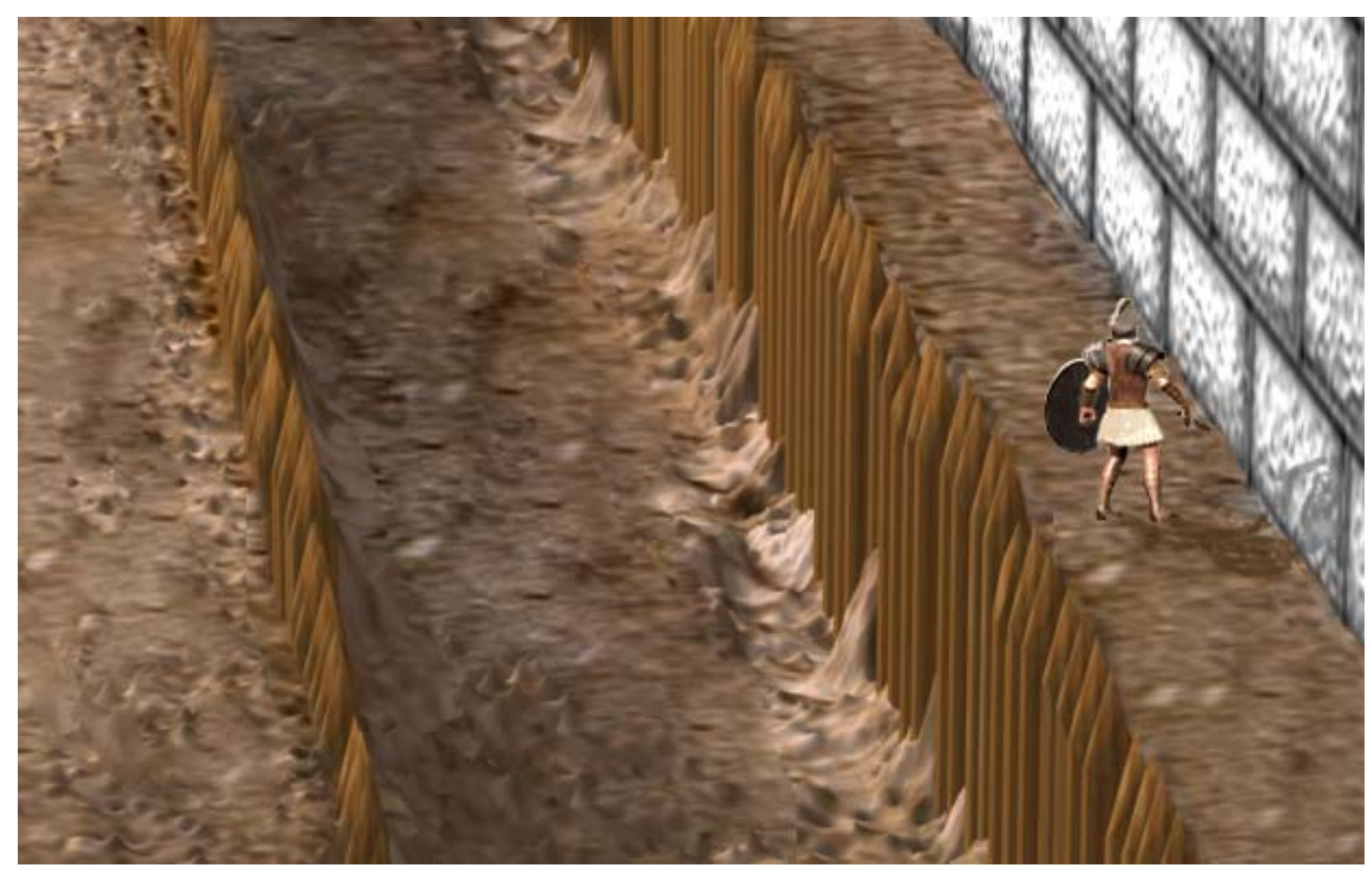

Figure 2: Possible interpretation of the Achaean trench

\subsection{Pavement construction and road infrastructure}

There are numerous references of road infrastructure that connected the Mycenaean cities, but also of the road network within each city. Telemachos travels with a chariot from Sparta to Pylos to collect information about the whereabouts of his father, Odysseus. Characteristic is the repeated expression that at the end of the day "the sun sets and all the roads darkened" (Odyssey, O182-185). Such references are used for the roads outside the cities of Chalkida and Pylos.

Homer also describes the numerous trails of Ithaca, but again he carefully does not use the same epithets for all the roads. The road that connected Evmaios' barn to

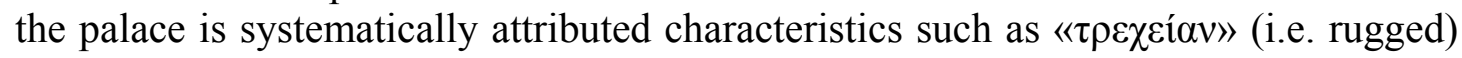

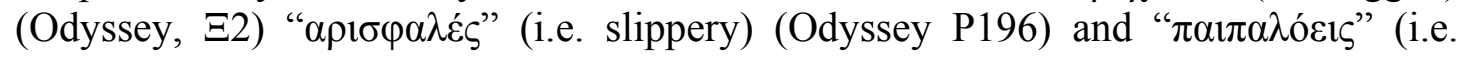
craggy, rugged) (Odyssey, P204-205) while other roads are characterized as crowded with people (Iliad, O682). This difference in characterization is not again random.

However, the most interesting remark regarding road infrastructure can be found in the Iliad ( $\Psi 419-422)$ where Menelaos and Antilochos are racing with chariots as part of athletic games to honor the death of Patroclos. At some point the road is partly destroyed and becomes narrower and Menelaos warns Antilochos not to attempt to overtake him by exiting the narrow road because he will destroy his chariot. This interesting piece of information suggests that different types of roads with different specifications existed and chariots could only travel on roads that met certain specifications. The poet also explains that the destruction of the road was caused by ponded rainfall water that induced soil settlement and damage to the road. The information provided by Homer is consistent with the archaeological findings of 
the Mycenaean highway infrastructure as presented by Jansen [10]. Jansen performed a survey of the currently preserved Mycenaean highways with particular focus on the road system in the vicinity of the city of Mycenae. He identifies at least four main roads, that he calls highways. These main roads consisted of high terracing walls and bridges in an effort to avoid steep grades and facilitated the transportation of wheeled traffic. Wheel ruts are still preserved in several locations along these roads. However, Jansen did not identify main roads connecting the various Mycenaean states, but it is likely that such roads were continuously used, improved and subsequently overlayed by roads during the classic, the Roman, the Byzantine period and eventually were covered by the present highway infrastructure.

\subsection{Port facilities}

Ports are mentioned numerous times in the Odyssey. However, it is not entirely clear what the poet means when he uses the word "port". On some occasions the term is used to describe a natural gulf protected from the waves and winds, while other times it is used to describe an engineered harbor, possibly by fill placement with organized facilities. Homer mentions that Ithaca had wide ports while the island of the Phaeacians does not have ports or other mooring areas except steep rocky coastlines (Figure 1). When Odysseus enters the city of the Phaeacians, he is impressed by the double port and the supporting infrastructure that is used to protect their ships. Next to the port, stones were brought and were embedded in the soil so that the ships' masts and sails can be repaired (Odyssey, Z262-271). This is a well-organized port of a strong navy power. The Phaeacians mention that their power is based on their fast ships and not in their land army. In another occasion, Evmaios refers to his city of origin and reports that it has a well-known port and many roads (Odyssey, O471-474). Finally, Odysseus reports that the island of Pharos has a protected port and a spring from which ships can collect water prior to embarking (Odyssey, $\Delta 358-360$ ).

\subsection{Embankments}

In the Iliad (E87-92) the attacking fury of the hero Diomedes is compared to the fury of a flooding river that cannot be controlled even by reinforced embankments. Homer refers to the type of projects that Mycenaeans are well known for: The construction of embankments and hydraulic works. These types of projects have been studied by various researchers [6, 11, 12]. Knauss [6] presented different types of Mycenaean retaining walls and embankments based on archaeological findings. More recently, Aravantinos et al. [13] presented archaeological findings of a Mycenaean embankment near the city of Orchomenos that could explain the embankment reinforcement that Homer is referring to. The embankment had a width of $8 \mathrm{~m}$ and consisted of two parallel stonewall faces $2 \mathrm{~m}$ wide and a core of yellowish mud in between. The element of interest is the existence of four internal transverse walls that connected the two sides of the embankment and operated as struts.

\section{CONCLUSIONS}

The information provided by Homer on topics related to engineering geology and geotechnical engineering is remarkable, given the scope of the poems. Homer is apparently careful in the selection of words used to describe various geologic environments and phenomena. The words are selected not only based on literary 
criteria, but are also accurate. Homer's remarks also suggest that some basic understanding of the geologic processes existed at his time, probably as a result of observations of the environment. This is not surprising, as the preservation and growth of agricultural societies were greatly dependent on the environment. Of interest is also the information collected on various types of geotechnical engineering projects mentioned in the poems, which include deep excavations, road infrastructure, embankments and port facilities. In the poems there are indications of the existence of construction practices and projects built to certain specifications. The information provided by Homer is largely consistent with the archaeological findings.

\section{NOTES}

The Perseus Digital Library of Tufts University (http://www.perseus.tufts.edu/ ) was used for the study of the frequency of occurrence of various epithets in the Homeric poems. The authors would also like to thank Dr. Edmund Medley of GeoSyntec Consultants for his valuable review and comments. Additional studies related to the history of geotechnical engineering and engineering geology are available at the Geoengineer website at http://www.geoengineer.org .

\section{BIBLIOGRAPHY}

[1] Schliemann, H. Troy and its remains. Reprint of the 1875 edition, Arno Press, New York, 1976

[2] Schliemann, H. Mycenae: A narrative of researches and discoveries at Mycenae and Tiryns. Reprint of the 1880 edition. Arno Press, New York, 1976.

[3] Homer, The Iliad, translated by Robert Fagles, Penguin Classics, 1998.

[4] Homer, the Odyssey, translated by Robert Fagles, Penguin Classics, 1997.

[5] The Perseus Digital Library, Ancient Greek versions of the Iliad and Odyssey http://www.perseus.tufts.edu/

[6] Knauss, J. Post-Helladic hydraulic works: Studies for the infrastructure of hydraulic works for water management during the Mycenaean times (in Greek). Society for the study and promotion of the Hellenic history, 2002.

[7] Zekkos, D., Manousakis, J., Athanasopoulos, A. G. Geotechnical engineering practice in the Mycenaean civilization $(1600-1100 \quad B C), 2^{\text {nd }}$ International Conference on Ancient Greek Technology, Athens, 17-21 October 2005. Also available at http://www.geoengineer.org

[8] Spyropoulos, P. I. Chronicle of earthquakes in Greece from antiquity to present (in greek). Dodoni Publications, 1997.

[9] Isiod. Complete works (ancient text and translation). Publisher Kaktos, 1993.

[10] Jansen, A. G. A study of the remains of Mycenaean roads and stations of bronzeage Greece, The Edwin Mellen Press, Ltd. 2002.

[11] Iakovidis, S. E. Gla and the Kopais in the 13th century BC, Library of the archaeological society at Athens, No. 221, 2001.

[12] Balcer, J. M. The Mycenaean dam at Tiryns, American Journal of Archaeology, Vol. 78, No.2, pp. 141-149, April 1974.

[13] Aravantinos, B., Kountouri, E., Fappas, I. The Mycenaean drainage system of Kopaids: New facts and first appraises, $2^{\text {nd }}$ International Conference on Ancient Greek Technology, Athens, 17-21 October 2005. 